AGRITECH, Vol. 37, No. 3, Agustus 2017, Hal. 280-287

DOI: http://doi.org/10.22146/agritech.10377

ISSN 0216-0455 (Print), ISSN 2527-3825 (Online)

Tersedia online di https://jurnal.ugm.ac.id/agritech/

\title{
Pengaruh Pelapis Dapat Dimakan dari Karagenan terhadap Mutu Melon Potong dalam Penyimpanan Dingin
}

\author{
Effects of Carrageenan Edible Coating on Fresh Cut Melon Quality in Cold Storage \\ Doddy Andy Darmajana*, Nok Afifah, Enny Solihah, Novita Indriyanti
}

Pusat Pengembangan Teknologi Tepat Guna, Lembaga Ilmu Pengetahuan Indonesia,

Jl. K.S. Tubun No. 5 Subang 41213, Indonesia

Email: doddyandy@yahoo.com

Submisi: 14 Januari 2016; Penerimaan: 4 Mei 2017

\begin{abstract}
ABSTRAK
Konsumsi buah melon potong segar meningkat beberapa tahun terakhir karena manfaat kesehatannya. Salah satu alternatif terbaru untuk mengurangi penurunan kualitas yang disebabkan oleh pengolahan minimal buah-buahan adalah pengembangan edible packaging (kemasan dapat dimakan). Mereka diharapkan dapat memperpanjang umur simpan buah melon potong. Tujuan penelitian untuk mempelajari efektivitas edible coating dan edible film untuk menjaga kualitas buah melon potong segar selama penyimpanan pada temperatur $10^{\circ} \mathrm{C}$ selama 6 hari. Larutan edible dibuat dengan melarutkan $2 \%$ karagenan, $1 \%$ gliserol, dan $0,5 \%$ tween 80 dalam aquadest pada temperatur $70-80$ ${ }^{\circ} \mathrm{C}$. Larutan ini digunakan sebagai sistem pelapisan dengan metode pencelupan dan metode pembungkusan. Buah melon tanpa pelapis disiapkan sebagai kontrol. Pengukuran kualitas buah melon meliputi susut bobot, kekerasan, total padatan terlarut, nilai $\mathrm{pH}$, dan total plate count. Hasil penelitian menunjukkan bahwa untuk semua perlakuan terjadi peningkatan susut bobot, total padatan terlarut, dan angka lempeng total selama penyimpanan, sementara kekerasan dan $\mathrm{pH}$ mengalami penurunan. Dalam hal mikrobiologi, pelapisan meningkatkan masa simpan buah melon potong (hingga 2 hari) dibandingkan dengan kontrol.
\end{abstract}

Kata kunci: Karagenan; edible coating; edible film; melon

\begin{abstract}
Recently, fresh-cut melon consumption has been increasing due to the health benefits. One of methods to reduce the decay of quality by minimal processing of fruits is edible packaging. This method may extend the shelf-life of fresh-cut melon. The objective of this research was to study the effectiveness of the edible coatings and edible films to maintain the quality of fresh-cut melon during storage at $10^{\circ} \mathrm{C}$ for 6 days. The edible solutions were prepared by dissolving carrageenan of $2 \%$, glycerol of $1 \%$, and tween 80 of $0.2 \%$ into aquadest. These solutions were used as coating systems by dipping and wrapping method. Uncoated fruits served as controls. Quality was measured in terms of weight loss, hardness, soluble solids, $\mathrm{pH}$ value, and total plate count. The result revealed that for all treatments the value of weight loss, soluble solid content, and total plate count increased during storage whilst hardness, $\mathrm{pH}$, decreased. In terms of microbiological, the coating improved the shelf-life of fresh-cut melon (up to 2 days) compared to the controls.
\end{abstract}

Keywords: Carrageenan; edible coating; edible film; melon 


\section{PENDAHULUAN}

Melon (Cucumis melo L.) merupakan buah terpenting keempat pada pangsa pasar buah segar di dunia (Supapvanich dan Tucker, 2011). Indonesia memproduksi lebih dari 125.207 ton melon pada tahun 2013 dan meningkat mencapai 150.356 ton pada tahun 2014 (BPS, 2015). Melon termasuk salah satu buah tropis yang eksotis, karena memiliki warna, rasa dan aroma yang khas. Selain itu bentuk dan teksturnya juga memberi daya tarik tersendiri. Di lingkungan tropis seperti Indonesia, temperatur dan kelembaban udara yang tinggi sering terjadi sepanjang tahun. Hal ini mempengaruhi kualitas buah setelah panen, termasuk kualitas buah melon.

Konsumen saat ini mempunyai harapan yang lebih terhadap kualitas buah diantaranya lebih bernutrisi, lebih aman dimakan, dan lebih lama masa simpannya. Selain itu, dalam mengkonsumsi buah, konsumen juga sangat menginginkan buah tersedia dalam kondisi segar dan menarik pada saat disajikan dengan tingkat kematangan yang seragam dan siap konsumsi. Awalnya, buah potong hanya bisa diperoleh di restoran atau disuplai oleh layanan industri makanan, dimana komoditi tersebut dijual ke konsumen dengan waktu singkat. Saat ini buah potong telah meluas ke supermarket untuk merespon kebutuhan konsumen (Olivas dan BarbosaCánovas, 2009). Namun sifat mudah rusak (perishable) buahbuahan menyebabkan umur simpan buah potong ini sangat singkat dan rawan terhadap kemunduran kualitas warna, rasa, aroma dan tekstur. Kemunduran kualitas ini disebabkan oleh aktivitas metabolisme yang masih berlangsung pada buah selama masa simpan. Aktivitas ini akan mempercepat kematangan dan dapat menyebabkan kebusukan pada buah jika tidak dikendalikan (Alsuhendra dkk., 2011).

Beberapa penanganan pasca panen seperti penkondisian/ pengkontrolan atmosfer pengemasan dan irradiasi gama telah diaplikasikan untuk mengatasi masalah pasca panen buah (Hamzah dkk., 2013). Metode komersial yang paling banyak digunakan adalah penyimpanan pada temperatur rendah (4-8 ${ }^{\circ} \mathrm{C}$ ). Penggunaan edible packaging telah banyak dipelajari sebagai alternatif yang baik untuk mempertahankan buahbuahan termasuk buah potong segar.

Edible packaging adalah jenis bahan yang digunakan untuk membungkus (yaitu, coating atau wrapping) berbagai makanan untuk memperpanjang umur simpan produk yang dapat dimakan bersama-sama dengan makanan (Pavlath dan Orts, 2009). Ada 2 jenis edible packaging, yaitu yang berbentuk lapisan (edible coating) dan lembaran (edible film) (Krochta, 1992). Lapisan atau lembaran film ini berfungsi untuk membantu melindungi produk dari kerusakan mekanis seperti tekanan dan goresan serta menghambat penurunan mutu dengan mengurangi transmisi uap air, aroma, dan lemak dari bahan pangan yang dikemas.
Coating dapat dilakukan dengan berbagai cara yaitu dengan mencelupkan produk ke dalam larutan yang mengandung bahan-bahan film, sehingga bahan film dapat langsung mendeposit pada permukaan makanan, atau dengan membuat lembaran film dari larutan atau melalui thermo formation untuk menutupi permukaan makanan. Cara paling mudah untuk mengaplikasikan packaging film adalah langsung dari larutan, produk akan menyerap bahan pelapis yang diperlukan dengan jumlah yang tepat untuk membentuk lapisan yang diinginkan, yang ketika kering membentuk lapisan pelindung pada permukaan makanan (Pavlath dan Orts, 2009).

Edible coating dan edible film dapat dibuat dari bahan hidrokoloid (polisakarida dan protein) dan lemak atau campuran keduanya. Edible film yang dibuat dari hidrokolid memiliki keunggulan dalam sifat mekanis dan kemampuan yang baik untuk melindungi produk dengan jalan menghambat perpindahan oksigen, karbondioksida dan lipid, namun kurang bagus dalam menahan migrasi uap air (Falguera dkk., 2011). Karagenan merupakan hasil ekstraksi rumput laut dari family Rhodophycae yang mempunyai sifat hidrofilik dan berfungsi sebagai pengental, penstabil, penggumpal, pengemulsi, dapat membentuk gel, serta dapat berinteraksi dengan bahan kimia yang ada dalam makanan (Prajapati dkk., 2014). Karagenan merupakan campuran kompleks beberapa polisakarida yang mempunyai sifat yang baik sebagai pembentuk lapisan tipis (Skurtys dkk., 2010).

Bahan tambahan dapat ditambahkan dalam proses pembuatan edible film adalah plasticizer yang berguna meningkatkan fleksibilitas dan elastisitas film, dan meningkatkan permebialitas terhadap gas, uap air, dan zat terlarut. Beberapa food grade plasticizer adalah gliserol, manitol, sorbitol, dan sukrosa. Untuk mendapat keseragaman yang lebih baik dapat ditambahkan surfaktan ke dalam larutan untuk mengurangi tegangan permukaan dan superficial water activity, yang akhirnya dapat mengurangi kehilangan air. Jenis-jenis surfaktan di antaranya karboksi metil selulosa (CMC), tween 80, dan gum.

Beberapa penelitian pengembangan edible coating berbasis polisakarida yang diaplikasikan pada buah potong telah dilakukan untuk memperpanjang umur simpan dan memperlambat pematangan beberapa buah-buahan (Nurhayati dkk., 2014; Brasil dkk., 2012; Oms-Oliu dkk., 2008; Chien dkk., 2007). Penelitian-penelitian tersebut lebih fokus kepada jenis dan konsentrasi polisakarida dan plasticizer. Oleh sebab itu, penelitian ini diarahkan pada metode pelapisan edible packaging pada buah potong.

Penelitian bertujuan untuk mempelajari efektivitas teknik pelapisan edible packaging dari karagenan dan gliserol untuk mempertahankan kualitas buah melon potong selama penyimpanan pada suhu refrigerator selama 6 hari. 


\section{METODE PENELITIAN}

\section{Alat dan Bahan}

Peralatan yang digunakan meliputi timbangan digital, beaker glass $500 \mathrm{~mL}$, gelas ukur $100 \mathrm{~mL}$, termometer, hot plate, magnetic stirrer, dan plat akrilik. Alat yang digunakan untuk analisa antara lain timbangan digital, $\mathrm{pH}$ meter, penetro meter, dan cawan petri.

Percobaan menggunakan buah melon yang dibeli dari pasar tradisional di Subang, Jawa Barat. Bahan-bahan untuk pembuatan edible film berupa tepung Kappa- karagenan dari Setia Guna Bogor, gliserol dan tween 80 diperoleh dari Brataco (toko bahan kimia) di Bandung.

\section{Pelaksanaan Penelitian}

Penelitian ini dilakukan dengan memvariasikan cara pengemasan edible packaging. Perlakuan P1 (kontrol) untuk buah yang tidak dilapisi edible packaging, perlakuan P2 (wrapping) untuk pengemasan buah dengan dibungkus edible film, dan perlakuan P3 (coating) untuk pengemasan buah dengan cara dicelup. Masing-masing perlakuan diulang tiga kali.

Penentuan konsentrasi karagenan dan gliserol didasarkan pada hasil perlakuan terbaik dari penelitian Tamaela dan Lewerissa (2007). Pembuatan edible packaging tunggal dari karagenan dengan cara melarutkan 2\% (b/v) karagenan ke dalam akuades sambil diaduk dan dipanaskan sampai suhu $70{ }^{\circ} \mathrm{C}$. Kemudian $1 \%$ (v/v) gliserol ditambahkan beserta $0,2 \%(\mathrm{~b} / \mathrm{v})$ tween 80 . Larutan kemudian dipanaskan dan diaduk selama 10 menit pada suhu $70-80{ }^{\circ} \mathrm{C}$. Gelembung udara yang terdapat pada larutan dihilangkan. Larutan tersebut selanjutnya digunakan untuk melapisi buah melon. Sedangkan untuk pembuatan lembaran film, sebanyak $85 \mathrm{~mL}$ larutan dituangkan pada plat akrilik $20 \times 20 \mathrm{~cm}^{2}$ kemudian dikeringkan dengan oven pada suhu $50{ }^{\circ} \mathrm{C}$ selama 24 jam. Film dilepas dan disimpan dalam ruangan dengan suhu $25^{\circ} \mathrm{C}$ selama satu minggu sebelum digunakan.

Buah melon, pisau, dan papan potong dicuci dengan air mengalir. Pisau dan papan potong didisinfeksi menggunakan $70 \%$ etanol selanjutnya dikeringkan. Buah melon dikupas

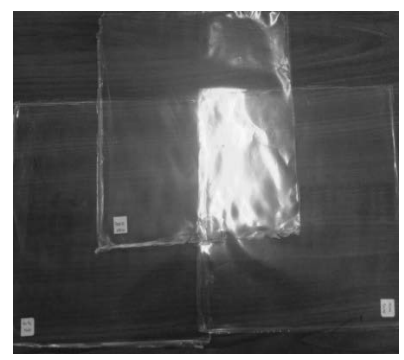

Gambar 1. (a) Edible film karagenan

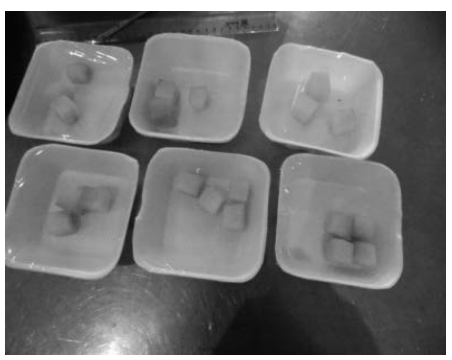

(b) Edible coating buah melon potong dan dipotong kubus dengan ukuran kira-kira $2 \mathrm{~cm} \times 2 \mathrm{~cm} \times$ $2 \mathrm{~cm}$. Potongan melon disimpan dalam pengemas styrofoam dan dibungkus dengan plastik wrapping komersial sebagai kontrol. Coating dilakukan dengan mencelupkan potongan buah ke dalam larutan yang dapat dimakan (edible) pada suhu $60{ }^{\circ} \mathrm{C}$ selama 30 detik. Selanjutnya dikeringkan pada temperatur kamar selama 10 menit. Edible film (wrapping) dilakukan dengan membungkus potongan buah dengan lembaran edible film berukuran $8 \times 8 \mathrm{~cm}^{2}$. Potongan-potongan buah kedua perlakuan tersebut selanjutnya ditempatkan pada pengemas styrofoam dan dibungkus dengan plastik wrapping komersial. Semua sampel kemudian disimpan pada suhu 10 ${ }^{\circ} \mathrm{C}$ selama 6 hari. Pengambilan sampel dilakukan secara acak untuk setiap kali analisa.

\section{Analisa}

\section{Susut bobot}

Nilai susut bobot diperoleh dengan membandingkan berat buah pada hari ke-n dengan berat buah pada hari ke(n-1). Pengukuran susut bobot buah dilakukan dengan cara penimbangan menggunakan timbangan analitik. Hasil penimbangan dinyatakan dalam persen bobot yang dihitung dengan Persamaan 1 (Alhassan dan Abdul-Rahaman, 2014).

$\%$ susutbobot $=\frac{W_{0}-W_{n}}{W_{0}} \times 100 \%$

$$
\begin{aligned}
& \text { Keterangan: } \\
& W o=\text { berat awal buah, } \mathrm{g} \\
& W n=\text { berat buah hari ke- } \mathrm{n}, \mathrm{g}
\end{aligned}
$$

\section{Kekerasan buah}

Pengamatan kekerasan buah dilakukan dengan alat universal penetrometer Humboldt type $H 1200$ menggunakan spindle bernomor H-1270. Nilai kekerasan buah ditentukan dari tingkat ketahanan buah melon potong terhadap tekanan jarum penusuk alat penetrometer yang ditunjukkan oleh kedalaman masuknya jarum penusuk dari permukaan buah selama 5 detik. Penusukan diambil pada bagian tengah dan pada pinggir atau ujung buah. Data yang diperoleh merupakan hasil rata-rata dari ketiga data pengukuran tersebut (Sarifudin dkk., 2015).

\section{Total padatan terlarut (TPT)}

Total padatanterlarutdiukurmenggunakanrefractometer. Sampel buah melon dihomogenkan dengan menggunakan cawan petri dan mortar. Bagian cairan dari sampel tersebut dipisahkan dari bagian daging dengan menggunakan alat tekan yang sudah tersedia, sehingga air buah melon keluar. Prisma refractometer terlebih dahulu dibersihkan dengan 
aquades agar tidak ada kotoran lain yang ikut terukur. Sebanyak 1-2 tetes cairan buah melon dimasukkan ke dalam prisma refractometer, kemudian dilakukan pembacaan nilai total padatan terlarut yang dinyatakan dengan $\%$ brix (Alhassan dan Abdul-Rahaman, 2014).

\section{pH}

Tingkat keasaman $(\mathrm{pH})$ sampel dapat diukur menggunakan alat $\mathrm{pH}$ meter. Sebelum memulai pengukuran alat ini dikalibrasi terlebih dahulu dengan menggunakan buffer standar 4 dan 7, kemudian elektroda dibilas dengan akuades dan dikeringkan dengan kertas tisue. Sebanyak $30 \mathrm{~g}$ sampel dihancurkan sampai halus menggunakan mortar dan ditambahkan aquades dalam labu takar hingga volume 100 mL kemudian elektroda dicelupkan hingga tenggelam pada larutan sampel dan dibiarkan sampai diperoleh angka yang stabil sebagai nilai pH terukur (Nurhayati dkk., 2014).

\section{Total plate count (TPC)}

Sampel secara aseptik ditimbang $5 \mathrm{~g}$ dalam Erlenmeyer steril, kemudian ditambahkan $45 \mathrm{~mL}$ media BPW, dihomogenkan sampai suspensi pengenceran menjadi $10^{-1}$ atau sesuai pengenceran yang diperlukan. Dari setiap pengenceran diambil $1 \mathrm{~mL}$ dan dimasukkan ke dalam cawan petri dan dibuat duplo. Ke dalam setiap cawan petri dituangkan 15-20 mL media PCA suhu $\pm 45^{\circ} \mathrm{C}$, setelah media memadat cawan diinkubasi pada suhu $35-37{ }^{\circ} \mathrm{C}$ selama 48 jam. Jumlah koloni dalam sampel dapat dihitung dengan Persamaan 2 (BSN, 2006).

$$
N=\frac{\sum C}{\left[\left(1 \times n_{1}\right)+\left(0,1 \times n_{2}\right)\right] \times(d)}
$$

dimana:

$N=$ jumlah koloni per $\mathrm{mL}$ atau per $\mathrm{g}$

$\Sigma C=$ jumlah seluruh koloni yang dihitung

$n_{1}=$ jumlah cawan pengenceran pertama

$n_{2}=$ jumlah cawan pengenceran kedua

$=$ pengenceran pertama yang dihitung

Data yang diperoleh selanjutnya diuji secara statistik menggunakan analisis sidik ragam (ANOVA). Apabila terdapat perbedaan yang nyata antara perlakuan yang diuji, maka dilakukan pengujian lanjut menggunakan uji Duncan 5\%.

\section{HASIL DAN PEMBAHASAN}

\section{Susut Bobot}

Hasil pengukuran susut bobot selama penyimpanan buah melon potong antara perlakuan kontrol dan pengemas edible disajikan pada Gambar 2.

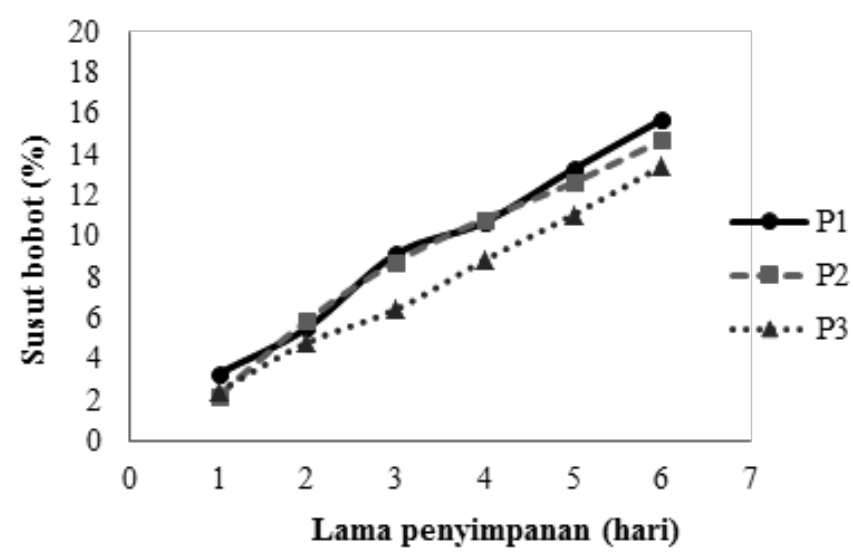

Gambar 2. Susut bobot buah melon potong selama penyimpanan pada suhu $10^{\circ} \mathrm{C}$

Salah satu fungsi pengemas adalah mengurangi penguapan air dalam buah sehingga buah tetap dalam keadaan segar karena tekanan uap air dalam sel tidak menurun. Selain itu secara ekonomi tidak akan berkurang, buah biasanya dijual berdasarkan bobot atau harga per satuan berat. Berdasarkan Gambar 1 dapat disimpulkan bahwa nilai susut bobot buah melon potong menunjukkan peningkatan selama penyimpanan. Nilai susut bobot buah melon potong tanpa pengemas edible lebih besar dari pada buah yang terlapisi oleh pelapis dapat dimakan, baik pada cara wrapping maupun cara coating. Berdasarkan uji statistik tidak terdapat perbedaan yang nyata dari ketiga perlakuan tersebut $(p \geq 0,05)$.

Edible coating pada buah dapat membuat susut bobot relatif rendah karena edible coating memiliki kemampuan menghambat laju kehilangan air dalam buah. Edible coating merupakan lapisan penahan yang baik terhadap air dan oksigen serta mampu mengendalikan laju respirasi. Susut bobot terjadi karena hilangnya komponen air dan volatil lainnya pada proses respirasi (penguapan air, gas dan energi) dan transpirasi (terlepasnya air dalam bentuk uap air) selama masa penyimpanan (Alsuhendra dkk., 2011).

Pada buah melon potong tanpa terlapisi kehilangan bobot berasal dari kandungan air dalam buah. Sementara pada buah melon potong dengan pelapisan, susut bobot terjadi karena kehilangan kandungan air dari bahan pelapis yaitu karagenan dan gliserol dan dapat terjadi kehilangan air dari buah. Hal ini terjadi adanya sifat permeabiltas coating terhadap uap air. Untuk film dengan formula yang digunakan dalam penelitian, kadar air buah saat pengemasan sekitar $85 \%$, sedangkan kadar air edible film 19,25\% dengan nilai water vapor transmission rate $51,40 \mathrm{~g} / \mathrm{m}^{2} /$ hari (Darmajana dkk., 2015). Hasil percobaan menunjukkan bahwa susut bobot P3 (Gambar 2), adalah yang terkecil, diduga susut bobot hanya disebabkan oleh kehilangan kandungan air dari bahan pelapis saja. Sementara pergerakan kandungan air dari 
buah melon potong menuju udara sekitar, akan tertahan oleh bahan pelapis. Selanjutnya kandungan air buah melon akan membuat kesetimbangan dengan kadar air edible film, dengan membutuhkan waktu yang lebih lama.

Karagenan merupakan bahan organik dengan struktur polimer yang larut dalam air dari rantai linear dari sebagian sulfat galaktan yang mempunyai potensi sebagai pembentuk lapisan tipis yang dapat mengakibatkan berkurangnya penyusutan, kebocoran, serta kerusakan rasa. Edible coating dari karagenan memiliki sifat permeabilitas yang baik sehingga dapat menahan laju uap air (sifat penghalang yang baik terhadap oksigen dan karbodioksida) (Tavassoli Kafrani dkk., 2016). K-karagenan merupakan komponen yang berkontribusi untuk menurunkan water vapor permeability karena k-karagenan memiliki gugus hidrofilik dalam jumlah sedikit pada edible film (Paula dkk., 2015).

\section{Kekerasan Buah}

Nilai kekerasan buah dapat digunakan sebagai indikator kesegaran buah atau tingkat kerusakan buah. Kekerasan buah terjadi karena tekanan cairan dalam sel masih cukup besar dan jaringan sel dalam buah belum mengalami kerusakan. Kadar air dalam sel buah sangat berpengaruh terhadap kekerasan buah. Buah yang sudah berkurang kadar airnya dibanding saat panen, akan menunjukkan gejala keriput sehingga buah akan lebih lunak. Kerusakan jaringan sel dalam buah juga dapat mengakibatkan kehilangan kadar air dalam buah (sineresis) dan menyebabkan buah lebih lunak. Hasil pengukuran kekerasan buah melon potong selama penyimpanan disajikan pada Gambar 3.

Hasil uji statistik menunjukkan bahwa nilai kekerasan buah melon potong ketiga perlakuan tidak berbeda secara nyata $(p \geq 0,05)$. Gambar 3 menunjukkan terjadinya penurunan kekerasan pada perlakuan kontrol, demikian juga pada perlakuan pelapisan buah melon potong dengan

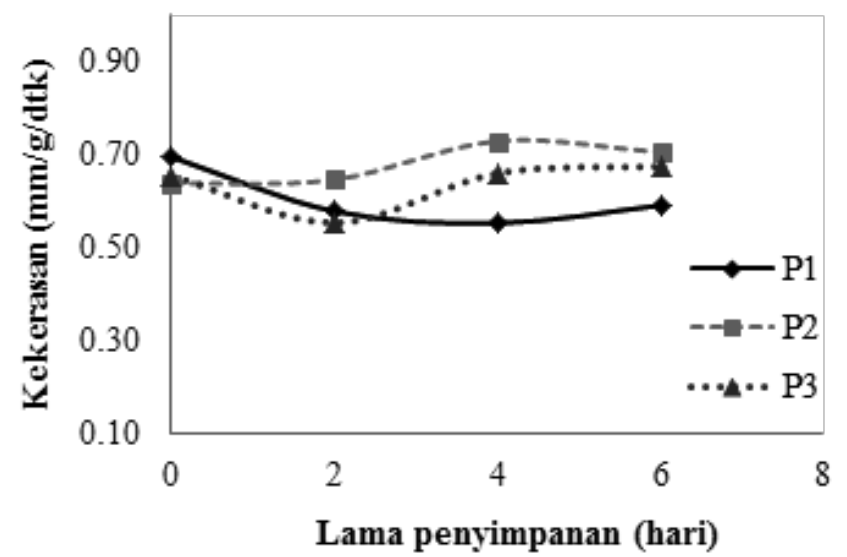

Gambar 3. Nilai kekerasan buah melon potong selama penyimpanan pada suhu $10^{\circ} \mathrm{C}$ edible coating. Hasil uji statistik pada setiap perlakuan memperlihatkan penurunan kekerasan sampel tersebut tidak berbeda nyata, atau dapat mempertahankan kekerasan buah. Penurunan kekerasan atau pelunakan pada buah akan terjadi selama proses pemasakan. Proses ini ditandai dengan berubahnya pektin tidak larut menjadi pektin yang larut dalam air, sebanyak lebih dari 40\%. Sehingga terjadi penurunan tekanan turgot sel. Perubahan tingkat keasaman dalam jaringan juga akan mempengaruhi aktifitas beberapa enzim diantaranya adalah enzim-enzim pektinase yang mampu mengkatalis degradasi protopektin yang tidak larut menjadi substansi pektin yang larut. Perubahan komposisi substansi pektin ini akan mempengaruhi kekerasan buahbuahan (Hartanto dan Sianturi, 2008).

Pada awal penyimpanan kadar air buah dan bahan pelapis relatif tinggi. Sementara proses pematangan buah mulai berlangsung, sehingga terdapat dua proses yaitu kehilangan kandungan air dari bahan (kontrol maupun perlakuan) dan proses pemasakan pada buah. Pada kontrol, karena tidak adanya bahan pelapis maka proses kehilangan air akan lebih banyak (pada waktu yang sama) dan proses perubahan fisiologis pada buah juga lebih cepat, seperti respirasi (tersedia oksigen lebih banyak).

Selain itu kekerasan buah akan menurun karena terjadi penurunan tekanan turgor sel. Preoses ini terjadi selama pemasakan buah (Genevois dkk., 2016). Namun setelah penyimpanan hari ke-2 kekerasan buah yang diberi perlakuan edible coating relatif stabil atau tidak mengalami penurunan dibandingkan dengan kekerasan buah pada kontrol. Hal ini dikarenakan pelapisan dengan edible coating mampu menghambat laju respirasi dan menekan terjadinya pelunakan buah (Widaningrum dkk., 2015).

\section{Total padatan terlarut (TPT)}

Terjadinya perombakan senyawa-senyawa komplek menjadi senyawa-senyawa yang sederhana selama proses pematangan buah menyebabkan naiknya total padatan terlarut. Kenaikan total padatan terlarut pada buah-buahan akibat terbentuknya gula-gula sederhana hasil degradasi pada fase kemasakan (Pantastico, 1993). Perubahan komponen mutu buah selama pematangan antara lain total padatan terlarut, total gula, total asam, vitamin C, pektin, dan lainnya akan menyebabkan perubahan terhadap warna, tekstur dan bau yang nyata. Hasil pengukuran nilai total padatan terlarut (TPT) buah melon potong selama penyimpanan pada berbagai perlakuan disajikan seperti pada Tabel 1 .

Berdasarkan Tabel 1 terlihat bahwa selama penyimpanan (6 hari) nilai TPT mengalami peningkatan, baik pada buah tanpa pengemas edible maupun pada buah dengan yang dikemas dengan cara coating dan wrapping. 
Tabel 1. Nilai TPT buah melon potong selama penyimpanan pada suhu $10^{\circ} \mathrm{C}$

\begin{tabular}{lcccc}
\hline \multirow{2}{*}{ Perlakuan } & \multicolumn{4}{c}{ Total padatan terlarut $\left({ }^{\circ}\right.$ Brix) } \\
\cline { 2 - 5 } & Hari-0 & Hari-2 & Hari-4 & Hari-6 \\
\hline P1 (kontrol) & ${ }_{\mathrm{v}}^{6} 6,50^{\mathrm{a}}$ & ${ }_{\mathrm{v}} 6,27^{\mathrm{a}}$ & ${ }_{\mathrm{v}} 6,23^{\mathrm{a}}$ & ${ }_{\mathrm{v}}^{6} 6,57^{\mathrm{a}}$ \\
P2 (wrapping) & ${ }_{\mathrm{v}}^{6} 6,63^{\mathrm{a}}$ & ${ }_{\mathrm{v}}^{6}, 57^{\mathrm{a}}$ & ${ }_{\mathrm{v}}^{6} 6,70^{\mathrm{a}}$ & ${ }_{\mathrm{v}} 8,20^{\mathrm{a}}$ \\
P3 (coating) & ${ }_{\mathrm{v}}^{6} 6,27^{\mathrm{a}}$ & ${ }_{\mathrm{v}} 7,27^{\mathrm{a}}$ & ${ }_{\mathrm{v}}^{6} 6,40^{\mathrm{a}}$ & ${ }_{\mathrm{v}} 7,07^{\mathrm{a}}$ \\
\hline
\end{tabular}

Keterangan:

a artinya dalam satu kolom, angka-angka yang diikuti oleh huruf yang sama menunjukkan bahwa perlakuan yang diuji tidak berbeda nyata pada taraf $5 \%$.

v artinya dalam satu baris, angka-angka yang didahului oleh huruf yang sama menunjukkan bahwa perlakuan yang diuji tidak berbeda nyata pada taraf $5 \%$.

Kenaikan nilai TPT menunjukkan bahwa selama penyimpanan, buah mengalami kerusakan jaringan atau meningkatnya kandungan gula (indikasi proses pemasakan/ ripening). Pada buah dengan pelapisan dan pembungkusan edible coating, nilai TPT lebih tinggi daripada tanpa perlakuan. Meskipun berdasarkan hasil uji Duncan 5\% tidak ada perbedaan yang nyata antara ketiga perlakuan. Hal ini diduga nilai TPT berasal dari kandungan gula dalam buah, juga dari bahan pengemas (karagenan) yang terlarut. Tingkat kelarutan karagenan dalam air dipengaruhi oleh tipe karagenan, temperatur larutan, $\mathrm{pH}$ larutan, adanya jenis ion tandingan dan zat-zat terlarut lainnya. Gugus hidroksil dan sulfat pada karagenan bersifat hidrofilik sedangkan gugus 3,6-anhidro-D-galaktosa lebih hidrofobik (Imeson, 2010). Lestari (2012) menyatakan bahwa penambahan karagenan berpengaruh terhadap nilai total padatan terlarut, $\mathrm{pH}$, dan viskositas. Hasil penelitian yang sama dilaporkan oleh Chien dkk. (2007), bahwa potongan buah yang dilapisi kitosan mempunyai nilai total padatan terlarut, titratable acidity dan kandungan ascorbic acid lebih tinggi.

\section{pH}

Hasil pengukuran tingkat keasaman $(\mathrm{pH})$ buah melon potong berbagi perlakuan selama penyimpanan disajikan pada Gambar 4. Gambar 4 menunjukkan bahwa pada awal penyimpanan semua perlakuan mempunyai $\mathrm{pH}$ yang hampir sama 6,27 - 6,50. Namun selama penyimpanan $\mathrm{pH}$ buah melon potong kontrol cenderung lebih rendah daripada buah melon potong yang dilapisi dan dibungkus edible packaging. Walaupun berdasarkan hasil uji Duncan 5\% tidak ada perbedaan yang nyata antara ketiga perlakuan. $\mathrm{pH}$ buah melon potong pada hari ke-6 sebesar 5,57 sedangkan buah melon potong yang dikemas edible packaging mempunyai pH sebesar 6,14-6,21.

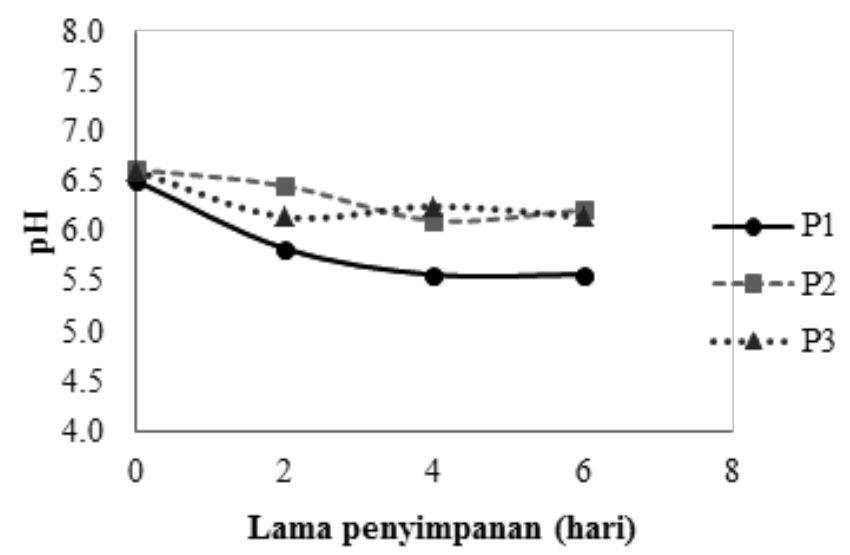

Gambar 4. Nilai $\mathrm{pH}$ buah melon potong selama penyimpanan pada suhu 10 ${ }^{\circ} \mathrm{C}$

Adanya edible coating/film dapat memperlambat laju respirasi buah melon potong sehingga nilai $\mathrm{pH}$ dapat lebih dijaga. Menurut Tafzi (2010) selama penyimpanan terjadi peningkatan total asam buah, selain akibat proses fisiologis buah itu sendiri, asam juga dapat dihasilkan karena terjadinya proses fermentasi. Proses ini menghasilkan asam-asam organik seperti asam laktat, asam butirat, dan lain-lain. Kenaikan total asam ini akan menurunkan nilai $\mathrm{pH}$.

Hasil ini sesuai dengan penelitian Nurhayati dkk. (2014) yang menunjukkan buah melon potong yang tidak dilapisi edible coating mempunyai $\mathrm{pH}$ lebih rendah dari buah yang dilapisi kitosan dengan $\mathrm{pH}$ 6,41 pada hari ke nol dan turun menjadi 4,68 pada hari ke-12. Velickova dkk. (2013) melaporkan bahwa $\mathrm{pH}$ semua sampel strawberi yang dilapisi kitosan dengan berbagai konsentrasi pada awal penyimpanan sebesar 4,4 dan turun menjadi sekitar 3,7-4,0 setelah penyimpanan 7 hari.

\section{Total Plate Count (TPC)}

Kelembaban dan kadar gula yang tinggi pada permukaan buah melon potong yang masih segar sangat sesuai bagi mikroorgnisme untuk tumbuh. Edible packaging pada buah potong berfungsi untuk memperlambat pertumbuhan mikroorganisme. Hasil pengukuran angka lempeng total (total plate count) disajikan pada Tabel 2 berikut.

Berdasarkan Tabel 2 terlihat bahwa angka lempeng total buah melon potong selama penyimpanan meningkat karena ada pertumbuhan mikroba. Buah melon potong yang dilapisi edible packaging umumnya mempunyai nilai angka lempeng total lebih rendah daripada buah melon yang tidak dilapisi. Menurut Santoso dkk. (2004) pertumbuhan mikroba pada bahan pangan disebabkan oleh penetrasi gas oksigen yang akan memacu berkembangnya mikroba aerobik untuk tumbuh. Edible packaging dapat menghambat penguapan air, memperlambat proses sineresis, dan menghambat 
Tabel 2. Nilai total plate count buah melon potong selama penyimpanan pada suhu $10^{\circ} \mathrm{C}$

\begin{tabular}{|c|c|c|c|c|}
\hline \multirow{2}{*}{ Perlakuan } & \multicolumn{4}{|c|}{ Total plate count (CFU/g) } \\
\hline & Hari-0 & Hari-2 & Hari-4 & Hari-6 \\
\hline P1 (kontrol) & $2,3 \mathrm{E}+04^{\mathrm{a}, \mathrm{b}}$ & $v, 1,6 \mathrm{E}+07^{\mathrm{a}}$ & $v, 1,0 \mathrm{E}+07^{\mathrm{a}}$ & $w^{2}, 4 E+07$ \\
\hline P2 (wrapping) & $4,1 E+04^{b}$ & $7,7 \mathrm{E}+05^{\mathrm{a}}$ & ${ }_{v, w} 1,1 \mathrm{E}+07^{\mathrm{a}}$ & ${ }_{\mathrm{w}} 2,1 \mathrm{E}+07$ \\
\hline P3 (coating) & $1,5 \mathrm{E}+04^{\mathrm{a}}$ & $1,8 \mathrm{E}+05^{\mathrm{a}}$ & $3,7 \mathrm{E}+05^{\mathrm{a}}$ & $1,1 \mathrm{E}+07$ \\
\hline
\end{tabular}

Keterangan:

a,b artinya dalam satu kolom, angka-angka yang diikuti oleh huruf yang sama menunjukkan bahwa perlakuan yang diuji tidak berbeda nyata pada araf $5 \%$.

v,w artinya dalam satu baris, angka-angka yang didahului oleh huruf yang sama menunjukkan bahwa perlakuan yang diuji tidak berbeda nyata pada taraf $5 \%$.

penetrasi gas oksigen karena matriks coating/film mempunyai ikatan yang kuat, rapat, dan kompak yang menyebabkan permeabilitas gas rendah.

Menurut Cahyana (2012) jumlah koloni mikroba yang diperbolehkan pada buah-buahan layak konsumsi sebanyak $6 \times 10^{6} \mathrm{CFU} / \mathrm{g}$. Artinya pada hari kedua buah melon kontrol sudah tidak layak sedangkan buah melon yang dikemas edible packaging masih layak. Hasil penelitian Cahyana dkk. (2012) menunjukkan buah melo n potong yang dilapisi kitosan masih layak konsumsi sampai hari kedua dengan jumlah mikroba 21,6 × $10^{5} \mathrm{CFU} / \mathrm{g}$. Penelitian Nurhayati dkk. (2014) memperlihatkan bahwa TPC buah potong melon potong yang tidak direndam kitosan terlalu banyak sehingga tidak dapat dihitung (TBUD) sedangkan pelapis buah melon potong terbaik adalah larutan kitosan 1\% yang mampu memperpanjang masa simpan sampai 4 hari dengan angka lempeng total bakteri $9,03 \times 10^{3} \mathrm{koloni} / \mathrm{g}$.

\section{KESIMPULAN}

Pada semua perlakuan terjadi peningkatan susut bobot, total padatan terlarut, dan angka lempeng total buah melon potong selama penyimpanan pada suhu $10{ }^{\circ} \mathrm{C}$, sementara kekerasan dan $\mathrm{pH}$ mengalami penurunan. Pelapisan buah melon potong dengan karagenan mampu memperpanjang masa simpan buah melon potong baik dengan metode pencelupan maupun metode pembungkusan edible film. Dalam hal mikrobiologi, pelapisan meningkatkan masa simpan buah melon potong (hingga 2 hari) dibandingkan dengan kontrol dengan angka lempeng total bakteri untuk kontrol, pelapisan metode coating dan metode wrapping berturut-turut 1,6E +07 , $1,8 \mathrm{E}+05$, dan 7,7E+05 CFU/g.

\section{UCAPAN TERIMA KASIH}

Kami sampaikan terima kasih kepada seluruh tim yang terlibat dalam Program Penelitian Unggulan LIPI "Aplikasi
Pengemas Edible untuk Buah-Buahan Tropis" dan kepada Pusbang TTG LIPI Subang atas semua dukungan dalam melaksanakan kegiatan ini.

\section{DAFTAR PUSTAKA}

Alhassan, N. dan Abdul-Rahaman, A. (2014) Technology and application of edible coatings for reduction of losses and extension of shelf life of cantaloupe melon fruits. International Journal of Scientific and Technology Reserach 3 (11): 241-246.

Alsuhendra, Ridawati dan Santoso, A.I. (2011). Pengaruh Penggunaan Edible Coating terhadap Susut Bobot, pH, dan Karakteristik Organoleptik Buah Potong pada Penyajian Hidangan Dessert. Skripsi. Fakultas Teknik Universitas Negeri, Jakarta.

Badan Pusat Statistik (2015). Tabel dinamis produksi tanaman buah melon Indonesia 2013-2014. http://www.bps. go.id/site/resultTab. [16 Oktober 2015].

Badan Standarisasi Nasional (2006). SNI 01-2332.3-2006 Cara uji mikrobiologi-Bagian 3: Penentuan angka lempeng total (ALT) pada produk perikanan. Badan Standarisasi Nasional.

Brasil, I.M., Gomes, C., Puerta-Gomez, A. Castell-Perez, M.E. dan Moreira, R.G. (2012). Polysaccharide-based multilayered antimicrobial edible coating enhances quality of fresh-cut papaya. LWT - Food Science and Technology 47: 39-45.

Cahyana, H., Christwardana, M. dan Rokhati, N. (2012). Pengaruh coating alginate-chitosan terhadap pertumbuhan mikroba pada buah melon kupasan. Jurnnal Teknologi Kimia dan Industri 1(1): 175-178.

Chien, P.J., Sheu, F. dan Yang, F.H . (2007). Effects of edible chitosan coating on quality and shelf life of sliced mango fruit. Journal of Food Engineering 78: 225-229.

Darmajana, D.A., Afifah, N., Sholichah, E. dan Indriyani, N. (2015). Laporan Kegiatan Aplikasi Pengemas Edible untuk Buah-Buahan Tropis. Pusat Pengembangan Teknologi Tepat Guna, Lembaga Ilmu Pengetahuan Indonesia, Subang (Tidak dipublikasikan).

Falguera, V., Quintero, J.P., Jimenez, A., Munoz, J.A. dan Ibarz, A. (2011). Edible films and coatings: Structures, active functions and trends in their use. Trends in Food Science and Technology 22: 292-303.

Genevois, C.E., Pla, M.F.D.E. dan Flores, S.K. (2016). Application of edible coatings to improve global quality of fortified pumpkin. Innovative Food Science and Emerging Technologies 33: 506-514. 
Hamzah, H.M., Osman, A., Tan, C.P. dan Ghazali, F.M.(2013). Carrageenan as an alternative coating for papaya (Carica papaya L. cv. Eksotika). Postharvest Biology and Technology 75: 142-146.

Hartanto, R. dan Sianturi, C. (2008). Perubahan kimia, fisika dan lama simpan buah pisang muli dalam penyimpanan atmosfir pasif. Prosiding Seminar Nasional Sains dan Teknologi-II 2008 Universitas Lampung, 17-18 November 2008

Imeson, A. (2010). Food stabilisers, thickeners and gelling agents. Blackwell Publishing Ltd, Oxford, England.

Krochta, J.M. (1992). Control of mass transfer in food with edible coatings and film. Dalam: Singh, R.P. dan Wirakartakusumah, M.A. (Eds). Advances in Food Engineering. CRC Press, Boca Raton, F.L.

Lestari, D.E. (2012). Pengaruh Konsentrasi Hidrokoloid Karagenan terhadap Mutu Minuman Jeli Bunga Rosela (Hibiscus sabdariffa L.). Skripsi. Universitas SAHID Jakarta, Jakarta.

Nurhayati, Hanum, T., Rangga, A. dan Husniati (2014). Optimasi pelapisan kitosan untuk meningkatkan masa simpan produk buah-buahan segar potong. Jurnal Teknologi Industri dan Hasil Pertanian 19(2): 161-178.

Oms-Oliu, G., Soliva-Fortuny, R. dan Martın-Belloso, O. (2008). Using polysaccharide-based edible coatings to enhance quality and antioxidant properties of fresh-cut melon. LWT - Food Science and Technology 41: 18621870.

Olivas, G.I. dan Barbosa-Cánovas, G. (2009). Edible films and coatings for fruits and vegetables. Dalam: Embuscado dan Huber. Editor. Edible Films and Coatings for Food Applications. USA (US), Springer. Hlm. 211-215.

Pantastico, E.R.B.(1993).Fisiologi Pasca Panen, Penanganan dan Pemanfaatan Buah-Buahan dan Sayuran Tropika dan Subtropika. Terjemahan Kamariyani. UGM Press, Yogyakarta

Paula, G.A., Benevides, N.M.B., Cunha, A.P., de Oliveira, A.V. (2015). Development and characterization of edible fi $\mathrm{lms}$ from mixtures of $\mathrm{k}$-carrageenan , i -carrageenan, and alginate. Food Hydrocolloids 47: 140-145.

Pavlath, A.E. dan Orts, W. (2009). Edible films and coatings: why, what, and how? Dalam: Embuscado dan Huber. Editor. Edible Films and Coatings for Food Applications. USA (US), Springer. Hlm. 2-8.
Prajapati, V.P., Maheriya, P.M., Jani, G.K. dan Solanki, H.K. (2014). Carrageenan: A natural seaweed polysaccharide and its applications. Carbohydrate Polymers 105: 97 112 .

Santoso, B., Saputra, D. dan Pambayun, R. (2004) Kajian teknologi edible coating dari pati dan aplikasinya untuk pengemas primer lempok durian. Jurnal Teknologi dan Industri Pangan 15(3): 239-244.

Sarifudin, A., Ekafitri, R. dan Mayasti, N.K.I. (2015) Evaluasi mutu fisikokimia dan organoleptik modifikasi kue satu berbasis tepung pisang. Jurnal Hasil Penelitian Industri 28(2): 95-103.

Skurtys, O., Acevedo, C., Pedreschi, F., Enrione, J., Osorio, F. dan Aguilera J.M. (2010). Food Hydrocoloid Edible Films and Coatings. Department of food Science and Technology Universidad de Santiago de Chile. http:// intrawww.ing.puc.cl/siding/datos/public files/profes/ fpedreschi GTSNWOEDCWJOGDA/Food\%20 Hydrocolloid\%20Edible\%20Films\%20and\%20 Coatings.pdf. [16 Oktober 2015].

Supapvanich, S. dan Tucker, G.A. (2011). Physicochemical changes in fresh-cut honeydew melon fruit during storage. African Journal of Agricultural Research 6(12): 2737-2742.

Tafzi, F. (2010) Kajian penggunaan edible coating untuk memperpanjang masa simpan buah nenas terolah minimal. Percikan 108: 11-15.

Tamaela, P. dan Lewerissa, S. (2007). Karakteristik edible film sari karagenan. Ichthyos 7(1): 27-30.

Tavassoli-Kafrani, E., Shekarchizadeh, H. dan MasoudpourBehabadi, M. (2016). Development of edible films and coatings from alginates and carrageenans. Carbohydrate Polymers 137: 360-374.

Velickova, E., Winkelhausen, E., Kuzmanova, S., Alves, V.D. dan Moldão-Martins. M. (2013). Impact of chitosanbeeswax edible coatings on the quality of fresh strawberries (Fragaria ananassa cv Camarosa) under commercial storage conditions. LWT - Food Science and Technology 52: 80-92.

Widaningrum, Miskiyah dan Winarti, C. (2015). Edible Coating based on sago starch with antimicrobe addition of lemongrass oil on red bell pepper. Agritech 35(1): 53-60. 